\title{
From the Dynamics of Population to the Application of Digital Revolution to Management of Shipping Companies
}

\author{
Alexandros M. Goulielmos ${ }^{1,2}$ \\ ${ }^{1}$ Department of Maritime Studies, Faculty of Maritime and Industrial Studies, University of Piraeus, Piraeus, Greece \\ ${ }^{2}$ Transport and Logistics Department, Business College of Athens, Athens, Greece \\ Email: ag@unipi.gr, am.goulielmos@hotmail.com, agoulielmos@bca.edu.gr
}

How to cite this paper: Goulielmos, A. M. (2020). From the Dynamics of Population to the Application of Digital Revolution to Management of Shipping Companies. Modern Economy, 11, 1155-1175.

https://doi.org/10.4236/me.2020.116084

Received: April 28, 2020

Accepted: June 21, 2020

Published: June 24, 2020

Copyright $\odot 2020$ by author(s) and Scientific Research Publishing Inc. This work is licensed under the Creative Commons Attribution International License (CC BY 4.0).

http://creativecommons.org/licenses/by/4.0/

(c) (i) Open Access

\begin{abstract}
Our scientific curiosity led us to study digital revolution-DR, specifically, we asked ourselves whether DR could revolutionize the management of ships, by bringing the object of management i.e. the vessels closer to her manager ashore. We discovered that curious scientists, like Mr. Malthus T R (born in 1766), emerged during the $1^{\text {st }}$ industrial revolution (1750) —and asked again ourselves what happened to his theory (1798)? We found that his theory-motivated by philanthropic considerations about working people, and in particular by the question if society can provide adequate means for their subsistence, caused three contradictory and important impacts. It seems that shipping companies will be obliged to abandon their traditional way of managing ships, i.e. from a long distance-described in some detail-and soon, after ceasing to discuss DR in world conferences-they will adopt DR, presented also in certain detail. Research frequently leads to unpleasant discoveries... Great human minds, unfortunately, supplied us with artificial realities, and so we named them, in this paper, utopians! Their utopia, however, was not about unimportant issues, but for: economic equality, disappearance of poor, equal income (and wealth) distribution; best quality of life and food; and for the benefits of technological progress! Society let technology to oblige people to learn a $2^{\text {nd }}$ profession during their life; to get unwillingly a pension at 65 years of age, by the force of law, while they are certainly fit to work till 80. In addition, our society, in an urgent need of an intensive care, has to beat COVID-19, which took already the life of 289,000 fellows by $12^{\text {th }}$ May, 2020 .
\end{abstract}

\section{Keywords}

Industrial Revolutions, Malthus' Model, Velhurst's Model \& Chaos Theory, 
Digital Revolution, Managing Ships from a Long Distance, Digital Management of Shipping Companies \& Ships, Global Abortions

\section{Introduction}

The 1st Industrial, or better Mechanical, Revolution, started 270 years ago. At that time the power of machines substituted for human power making less costly to produce goods in factories (than at home) (Robbins \& Coulter, 2018: p. 707). Reverend Malthus T R, (1766-1834), a historian of Sociology, caused indirectly... by his essays, the $1^{\text {st }}$ industrial revolution!

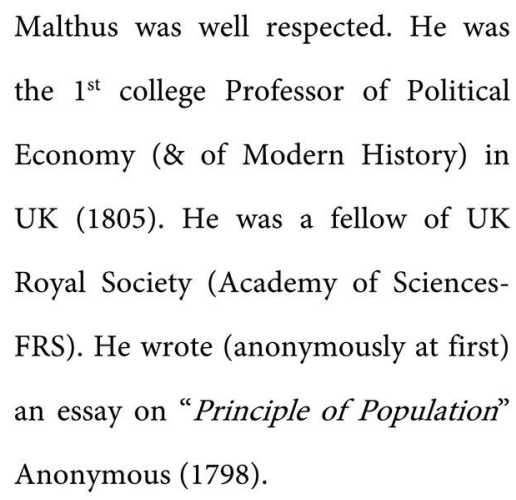

Malthus Theory: It deals with the growth of global population and its subsistence. It advanced 2 axioms, 1 suggestion and 1 assumption. Axioms are: 1) "It may safely be asserted that population, if unchecked, (will) increase in a geometrical ${ }^{1}$ progression, doubling within 25 years" (p. 238) (introduction, p. 18) (italics; \& one parenthesis added). 2) "The means of subsistence, ${ }^{2}$ under most favorable circumstances, could not possibly increase faster than in an arithmetical ratio (Vol. 1, p. 10, $2^{\text {nd }}$ essay; and in $1^{\text {st }}$ essay, p. 74). So, Malthus problem was one of disharmony between number of people and quantity of food.

Malthus was convinced for his $1^{\text {st }}$ axiom by the evidence provided by certain USA colonies, (between 1790 and 1840), where population doubled in 1 generation (i.e. in 25 years). Malthus' suggestion: Society has to proceed in "promoting, and where necessary, practicing, moral restraint” (bold \& italics added). He assumed "an isolated population, with neither emigration, nor immigration" (p. 46) Anonymous (1798).

However, we encountered a serious social phenomenon, which invalidated 
Malthus' $1^{\text {st }}$ assumption: globally $385 \mathrm{~m}$ (est.) embryos were aborted ${ }^{\beta}$ p.a.! In 25 years, the aborted embryos could have made the $7.7 \mathrm{~b}$ global population (est. in 2018) equal to $\sim 17.3 \mathrm{~b} \ldots$. This over-verifies Malthus $1^{\text {st }}$ axiom...And if global population did not verify Malthus model, individual countries, like India with $1.35 \mathrm{~b}$ people, $\mathrm{did}^{4}$.

Economists have to see a few further contemporary facts: 1) A single profession is not adequate for one's life time ${ }^{5}$ anymore. 2) Working life ends at 65 years of age ${ }^{6}$. However, many adverse social and economic consequences of current technological progress can be avoided by extending working life to 80 years of one's age...! In addition, though the quantity of production substantially increased due to industrial revolutions, the quality of it, and of our life, did not make analogous progress. Apropos research in EU initiated for some time to find-out whether... a type of cancer is created by food and by its means of storage!

Economists, we believe, have not only to advocate the maximization of profits, as used to do, but also to support the "maximization of the number of years people will have under perfect quality". As Jesus Christ-JC said: "humans will not live-out only on bread..."

Paper's aims are: 1) to present mathematically three population models. 2) To present digital revolution, exploring its possible application to management of ships; and 3) to summarize existing shipping management theory, and practice, so that to see what exactly we have to transform to achieve ships' digital management. The paper is organized in 6 parts, after literature review: the 1st deals with the question: "why Malthus Theory has failed"? The $2^{\text {nd }}$ deals with 3 fundamental questions, which any Society has to answer. The $3^{\text {rd }}$ deals with 3 growth-models of global population. The 4 th presents digital revolution. The $5^{\text {th }}$ outlines the traditional management of ships from a long distance. The $6^{\text {th }}$ deals with digital ship management. Finally, we conclude.

\section{Literature Review}

Godwin (1793), (1756-1836), a contemporary of Malthus, and utopian, soughtout equality among people inspired by French Revolution (1789). Engels (1844), (1820-1895), (p. 199+), a German, writer of the "Communist Manifesto" with

${ }^{3}$ We assumed that abortions are equal to $5 \%$ of total population (based on Greek experience); contraceptions (arbitrarily) are assumed to be $10 \%$. In USA “induced abortions" occur at a rate 1 out of 5 births (20\%) (Internet). An "induced abortion" is the cut of pregnancy, including cases where medication is taken (Jones \& Lopez, 2014).

${ }^{4} \mathrm{~A}$ “Food Corporation of India” formed having 77m tons of stock in March 2020.

${ }^{5}$ People have to pay additional money to learn the new technologies.

${ }^{6}$ Pensioners stress at least: the national health system, the funds destined for pensions, and the number of "old-age houses". It is better to keep people-of over 65 years of age-in work, if fit and if they want. The motive can be for them to get a rise in their final pension. Greek Government treated the right to be a pensioner like a holy cow, and timidly extended working age limit to 67 years for new pensioners. Greek State forbids pensioners to work by legislating penalties (e.g. to cut-off part of their pension)! At the same time government pays money to prolong life and is proud to announce a longer prospective life!

${ }^{7}$ See below comments on economic equality. 
Marx (in 1848), wrote: "the sham philanthropy... produced the Malthusian population theory, the crudest, most barbarous theory... ever existed, a system of despair, which struck down all those beautiful phrases about love of neighbor and world citizenship"...

Mill (1848), (1806-1873), wrote that Malthus focused on an unlucky attempt to give numerical precision to things, which do not admit it (II, xi, 6; rephrased). Place (1822) (1771-1854), an English, ... tailor, economist and political radical, like another Roosevelt ${ }^{8}$, suggested to people of UK birth-control ${ }^{9}$, as an effective ${ }^{10}$ mean to Malthus!

Darwin (1868), (1809-1882), found his basic idea for his theory "of evolution of species by natural selection" in... Malthus! He wrote (p. 361-2): "it flashed upon me that this self-acting process (of Malthus) would necessarily ${ }^{11}$ improve race" (parenthesis added); and "I had at length found-out the long-sought after law of nature, which solved the problem of the origin of species" (Blaug, 1997: p. 84)...

Marshall (1896), (1842-1924), (p. 30), wrote that the $2^{\text {nd }}$ essay ${ }^{12}$ of Malthus gave the most crushing answers ... written by a patient and hard-working person of science... (rephrased). Ricardo (1817), (1772-1823), chap. 32, admired Malthus, and argued that economic growth will end (due to scarcity of natural resources). He proved partially ${ }^{13}$ right due to the vertical rise of the price of oil during the 2 energy crises (1973 Oct.; 1979-1980), and in 2020, fluctuating ${ }^{14}$ till this day. This, severely harmed population, as countries in austerity programs (Greece e.g.) terminated the use of central heating!

Ricardo's argument was based on "law ${ }^{15}$ of diminishing returns", and on the fact that different agricultural lands have different fertilities ${ }^{16}$. "New economics"

\footnotetext{
${ }^{8}$ Explained in Appendix.

${ }^{9}$ The UK NHS provides contraceptive pills.

${ }^{10} \mathrm{CO}$-Christian Orthodoxy-allows no pregnancy-interruption or -avoidance; prior to marriage sexual activity is restricted; and those married have to obey certain rules. $\mathrm{CO}$ is in favor of large families of 6 , or at least 5, children. Catholic priests are not allowed to have a wife, while St. Peter had one.

${ }^{11}$ Nowadays science argues that the more adaptive will survive...

${ }^{12}$ Economists comment on $2^{\text {nd }}$ essay (as a piece of economics).

${ }^{13}$ For Keynes world economy is interrelated. When the price of oil rose by OPEC, (a Cartel of governments), (end 1973), the higher cost entered into the prices of almost all goods, which many imported by OPEC. Also, USA rescued the post $2^{\text {nd }}$ WW economy of Germany with 2 high loans; also, American technology made Germany competitive. Onassis saved post $2^{\text {nd }} \mathrm{WW}$ German shipbuilding (Goulielmos, 2017). EU saved Greek economy by providing loans. Some said that the world is one village, but "is it one family"?

${ }^{14}$ Due to COVID-19 the demand for oil fell dramatically, and so did oil price below \$20/b for Brent. S Arabia and Russia failed to agree to cut supply. Oil from schist needs $\$ 50 / \mathrm{b}$ to be viable. Greek oil costs $\$ 22 / \mathrm{b}$. Certain oil producing countries need $\$ 61 / \mathrm{b}$. One day of work at home means $376,000 \mathrm{~b}$ less benzene in USA. In European Continent 2 countries decided no measures for COVID-19; 23 are in quarantine and 14 are ready to ease their measures by end April 2020 or May.

${ }^{15}$ Economics christened laws certain economic relationships to mimic Physics. This mistake has to be rectified, so that economists to regain their reliability. If there were laws, economists would be "lawyers of the economy"! A law indicates something which is always happening!

${ }^{16}$ Research improved land cultivation (better seeds), use of fertilizers, creation of a digitalized agriculture, use of larger sizes of agricultural lands, drained-out lakes, irrigation projects done, and rivers changed their course, etc.; all these proved Ricardo wrong.
} 
remind that this "law" was only one out of 3 (Goulielmos, 2018a). Ricardo accepted the Malthusian view of population, leading to unlimited supply of labor (at a subsistence wage $)^{17}$. He assumed that accumulation will stop due to lack of profits in agriculture, and then in manufacturing. He extended Malthus suggesting imports (of foreign cheap grain).

Keynes (1933) commented on the correspondence of Malthus with Ricardo (pp. 140; 144), and remarked, taking the opportunity: "the complete domination of Ricardo on economics over 100 years" "was a disaster to the progress of economics" (italics \& bolds added)!! "If ... Malthus was the parent from which $19^{\text {th }} \mathrm{c}$. economics emanated, what much wiser and richer place the world would be" ${ }^{\prime \prime}$ ! He described Malthus "as the one who overlaid general economic principles by inductive verification of a pioneer...; the brilliance and the high spirits of a young man"...

About Digital Revolution: Digital Marketing emerged prior to Digital Management, we reckon. Digital companies-DCs are distinguished in those: (1) born-digital and (2) which wish to become ones. DCs are established after 1995, and whose operational models and capabilities use internet-era information and digital technologies as core competencies.

De la Boutetiere et al. (2019) established 5 keys to a successful digital transformation: 1) to have a (digital) leader, 2) to have the capability in building digital systems, 3) to empower one's workers, 4) to upgrade tools and 5) to establish (digital) communications.

In a McKinsey (2018) global survey, 85\% from the 1793 respondents, answered that their companies tried, the last 5 years, to become digital, but $75 \%$ of them failed... Shipping is at the stage of discussing digital revolution in global conferences... Ojala (2015), argued that "media" are very important. Griffith (2015) argued that "cloud computing"19 frees companies from having their own means to store data. Daugherty et al. (2015), argued that "internet of things" is essential, especially for industries.

Summarizing, Malthus was, no doubt, utopian ${ }^{20}$. This is so as poverty exists during the last 2000 years, as a sign of the inadequacy of means of subsistence! Malthus statistical evidence on growth of population was circumstantial, as argued also by Verhulst (1838). Malthus assumed indirectly no brain drain and no tourism $^{21}$. These are serious limitations for modern societies, while Malthus' conditions came back... due to COVID-19 in 2020.

Part 1: Why Malthus Theory failed?

Malthus failed to provide statistical evidence on the growth of means of sub-

\footnotetext{
${ }^{17}$ In 1815; 1846; in UK, imports of corn were prohibited to prevent price from falling.

${ }^{18}$ Keynes did not support Ricardo's writings, while he admired Malthus'!

${ }^{19}$ The $81 \%$ of respondents in McKinsey (2018) study confirmed this.

${ }^{20}$ Utopia offers a perfect social, or political system, existing in one's imagination, but hard, or impossible, to organize, or to implement it in real life.

${ }^{21}$ Greece used to feed about $25 \mathrm{~m}$ tourists in 3 summer months. Cruise ships are also floating restaurants for 5000 passengers.
} 
sistence $^{22}$. But he was definitely wrong also about his $1^{\text {st }}$ axiom (Table 1 ).

As shown, the growth of global population did not support Malthus ${ }^{23,24}$. Moreover, population increased by $1 \mathrm{~b}$ at eventually shorter intervals (from 14 years to 12) since 1960. Naturally, a larger population brings a larger number of children. In the past to gain $1 \mathrm{~b}$ people (from 1800 to 1930) society required 130 years, while most recently required only 12 years.

Of course, many causes halted the physiological growth of population. e.g. 1) the two global wars, where... $\sim 117 \mathrm{~m}$ people killed. Wars were frequent since Creation. 2) Three cities destroyed (Gomorrah; Sodom; Pompeii). 3) Family's size fell. Early males used to live long (to maximum 960 years like Methuselahs), and their children were minimum 5 per family. Modern families have from 2 members (mother and 1 child) to 4 maximum (Father-Mother and 2 children). 4) Incest was allowed at old times. 5) Abortions are in general legal and contraception is established.

If a society wants to reduce, or eliminate, abortions, has to start from rectifying its legal system (Table 2), we believe. The present legal framework of abortions is confusing and contradictory. To rectify it properly, a society must answer first the question: "When an embryo receives its soul and begins to live?"

Part 2: The 3 fundamental questions that Society has to answer Is society egalitarian, and are people (or should be) equal ${ }^{25}$ ? What Jesus Christ

Table 1. Global population (from prior to 1000 A.D. to 2018).

\begin{tabular}{|c|c|c|c|c|c|}
\hline Year & Population & Year & Population & Year & Population \\
\hline $\begin{array}{l}\text { Prior to } \\
1000 \mathrm{AD}\end{array}$ & $300 \mathrm{~m}$ & 1750 & $800 \mathrm{~m}$ & 1800 & $\begin{array}{c}1 b \\
(4 \mathrm{~m} \text { p.a.) }\end{array}$ \\
\hline 1930 & $\begin{array}{c}2 \mathrm{~b} \\
(7.7 \mathrm{~m} \text { p.a. })\left({ }^{*}\right)\end{array}$ & 1940 & $\begin{array}{c}2.3 \mathrm{~b} \\
(30 \mathrm{~m} \text { p.a. })\end{array}$ & 1960 & $\begin{array}{c}3 \mathrm{~b} \\
(35 \mathrm{~m} \text { p.a. })\left({ }^{* *}\right)\end{array}$ \\
\hline 1974 & $\begin{array}{c}4 \mathrm{~b} \\
(\sim 71.4 \mathrm{~m} \text { p.a. })\end{array}$ & 1987 & $\begin{array}{c}5 b \\
(77 \mathrm{~m} \text { p.a. })\end{array}$ & 1999 & $\begin{array}{c}6 b \\
\text { (82m p.a.) }\end{array}$ \\
\hline 2018 & 7.7b est. & & $\begin{array}{c}\left.{ }^{*}\right) \text { impact of } \\
1^{\text {st }} \mathrm{WW}\end{array}$ & $\begin{array}{c}(* *) \text { impact of } \\
2^{\text {nd }} \mathrm{WW}\end{array}$ & \\
\hline
\end{tabular}

Source: various; mainly internet.

22“The minimum level of consumption necessary for existence" is a concept due to classical economists. Classics introduced also the "Corn and Poor laws" (UK). Classical economists are considered those born since 1723 (i.e. Dr. Smith A.) until 1873, including Malthus and J S Mill, i.e. over a period of 150 years.

${ }^{23}$ In agricultural economies families bear many children. Children are killed during civil wars (e.g. Syria). Moreover, children are sought after for their organs; and when they try to immigrate to EU, many perish in Greek and Italian seas...

${ }^{24}$ Wars are now local and economical. World wars are feared for the potential use of nuclear weapons.

${ }^{25}$ "Equality" emerged in French revolution in 1789, one principle of utopia, based on "human Justice". Human Justice is satisfied, when a decision gives $1 / 2$ of what is claimed to 2 persons; "justice of equal sharing". The non-human justice is different and more important. Economists dealt with economic inequality (e.g. Sen, 1973). Sen is Nobel holder for Economy; Political Philosopher \& 86 years old Professor of Harvard University, who in an interview to Greek Sunday Press (26/04/2020), argued that Economics is a moral science \& Society is a mirror of moral values. "We live better if one helps the other", he said. He argued that real freedom is when one can acquire the goods that give value to his/her life. Economic equality is related to the distribution of income (see Goulielmos, 2018b). 
Table 2. The global legislation about abortions, 2019.

\begin{tabular}{|c|c|c|}
\hline Country & Legal regime & Comments \\
\hline Greece & $\begin{array}{l}\text { Greek constitution states: } \\
\text { - "The entire formation of one's } \\
\text { personality, including the right to } \\
\text { bear a child" (article 5; par. 1), } \\
\text { are protected" } \\
\text { - "One's right to live (article 5, par. 2; } \\
\text { article } 7 \text { par. 2)" is also protected } \\
\text { "Abortions are allowed during the } \\
\text { first } 12 \text { weeks of pregnancy }{ }^{26} \text { (since 1982) }\end{array}$ & $\begin{array}{l}\checkmark \quad \text { In Greek legal system there is } \\
\text { the principle that an embryo is } \\
\text { a legal person, if born alive. } \\
\checkmark \quad \text { Another principle says that } \\
\text { "with the probable course } \\
\text { of events an embryo } \\
\text { will be born alive"... }\end{array}$ \\
\hline USA & $\begin{array}{l}\text { The High Court admitted that } \\
\text { the right to abort exists }\end{array}$ & \\
\hline Germany & $\begin{array}{l}\text { The constitutional Court argued that life } \\
\text { exists-and thus it has to be protected-from } \\
\text { the moment of the implant of } \\
\text { fertilized egg on womb's wall. } \\
\text { This takes place few days after fertilization }\end{array}$ & $\begin{array}{l}\text { The law failed to recognize that the } \\
\text { implant of an (eternal) soul }{ }^{27} \text { into a } \\
\text { fertilized embryo takes place at the } \\
\text { same time as the } 2 \text { different sperms } \\
\text { meet (at conception). Embryo with } \\
\text { no eternal soul is dead, and embryo } \\
\text { with no body... is aborted. }\end{array}$ \\
\hline Ireland & $\begin{array}{l}\text { Relaxed the absolute prohibition of } \\
\text { abortions ruled there by religious rules }\end{array}$ & \\
\hline $\begin{array}{c}\text { El } \\
\text { Salvador }\end{array}$ & $\begin{array}{l}\text { A 21-years-of-age-woman, raped, in } \\
\text { El Salvador (a Central America country with } \\
\sim 7 \text { m people; Catholics), bore a baby dead }\end{array}$ & $\begin{array}{l}\text { She brought to Court } \\
\text { accused for murder }\end{array}$ \\
\hline Romania & An interesting case with zero (?) abortions... & \\
\hline
\end{tabular}

Source: Internet \& Press.

predicted about poverty? What Pareto (1909) found-out about the distribution of income in all societies?

Robinson (1962), p. 128, was clear that the distribution of income (and of wealth) has not be fair. We have, however, distinguished the distribution of income, which is unequal, from that of wealth, which has to be equal, in our opinion! In our epoch, the consequences of any war, anywhere, as well national poverty, are now exported, through aggressive emigration! People consider, as their inalienable right, to emigrate where they like!

Pareto $^{28},(1848-1923)$, was first to investigate ${ }^{29}$, in 1909 , whether economy is fair. If it is not, and if it also cannot be, we have a clear case of utopia among those arguing to the contrary! Malthus' principle of population could have 2 strong statistical tools for verification of his theory, we believe: 1) Normal dis-

\footnotetext{
${ }^{26}$ Exceptions are the pregnancies from rapes and dangering mother's health.

${ }^{27}$ Legislators had to know better; but do experts know? Psychologists, and all those dealing with human soul (psyche), they do not know what soul is, or they believe is a chemical thing!

${ }^{28}$ Ricardo interested in income distribution. After Keynes, economists focused on growth (moreover income distribution divided people), trying to make Keynes' model dynamic and long-term. In a larger pie, poor is expected to get a larger piece! In growth, all political parties agree. Right wing people used to be accused, however, for wanting the rich to become richer, and the poor to become poorer...!

${ }^{29}$ Professor of Economics at University of Lausanne (1892); successor of Prof. Walras L.
} 
tribution (1778-1809) $)^{30}$, emerged when Malthus was alive, and 2) Pareto's 1909 income curve, (when Malthus was dead).

For the $1^{\text {st }}$ test we need: personal income $(\mathfrak{E})$, its average $(\mathfrak{E})$ and its variance $\left(\sigma^{2}\right)$; for the $2^{\text {nd }}$ test we need: a (alpha, defined below) and minimum personal income $\mathrm{m}(\mathfrak{E})$. Important is that if national income is distributed according to normal distribution (Figure 1), egalitarianism is statistically proved.

The existence of utopia proved by Pareto ${ }^{31}$. While an accurate description of reality provided by Jesus Christ-JC ${ }^{32}$, when addressed to Juda of Iscariot: "The poor people will always be among you" (bolds added) ${ }^{33}$, he said. Moreover, religion, we believe, influences the decision to bear many or few children... We present below the 7 most populated nations worldwide and the \% of Christians (all dogmas) (Table 3).

Globally $^{34}$, Christians ${ }^{35}$ were $<1 / 3$ ( 31\%); Muslims 23\%, Hindu 15\%, unaffiliated $16 \%$ and unknown $15 \%$ (internet).

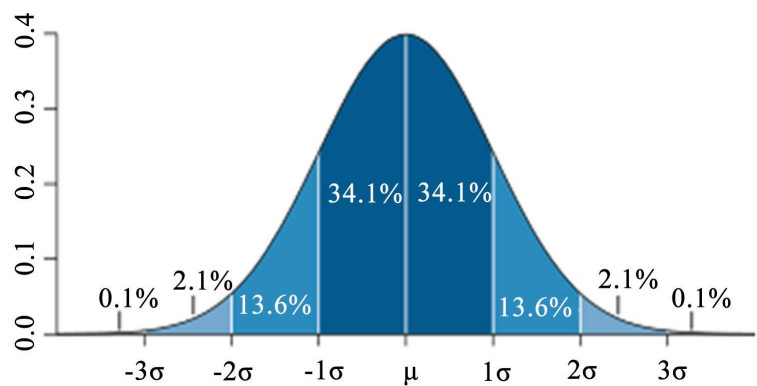

Figure 1. Normal distribution. Source: internet. $\mu=$ mean.

Table 3. The 7 most populated global countries and their \% in christians, 2018.

\begin{tabular}{cccc}
\hline Mainland ${ }^{36}$ China $^{37}:$ & India & USA & Indonesia \\
$\sim 5 \%$ & $2.5 \%$ & $78 \%$ & $\sim 10 \%$ \\
$(1.42 \mathrm{~m})$ & $(1.35 \mathrm{~m})$ & $(327 \mathrm{~m})$ & $(279 \mathrm{~m})$ \\
\hline \multirow{2}{*}{ Brazil $96 \%(209 \mathrm{~m})$} & Pakistan $<2 \%(212 \mathrm{~m})$ & Nigeria $49 \%(196 \mathrm{~m})$ & Total $\sim 4 \mathrm{~b}$ \\
\hline
\end{tabular}

Source: internet.

${ }^{30} \mathrm{~A}$ number of scientists contributed to the establishment of Normal Distribution-ND: Laplace in 1778 proved the "Central Limit Theorem"; Adrian, 1808; Gauss, 1809, who developed the formula of ND. Quetelet-mentioned below-applied ND to humanity.

${ }^{31}$ Wealthy persons do not like wealth equality, we believe. Employers, however, are responsible for the unequal income distribution... but they are right paying on merit!

${ }^{32}$ This is a passage from St. John's gospel (chap. 12, 8, NT). In this ( $\left.\chi \omega \rho i o v\right)$ : "Maria, sister of Lazarus of Bethany, in a sentimental action, used a valuable Myron from Valerian valued $\sim 9000$, (in today's prices), to prepare JC's body for burial.” Judas of Iscariot, on pure logic, and a thief, protested to JC as he lost the opportunity to "manage" this vast amount (=300 daily wages) and ... give it to Poor.

${ }^{33} \mathrm{~A}$ stronger point is how one treats wealth after it is obtained... (e.g. St. Matthew's case).

${ }^{34} \mathrm{We}$ had better to correlate Religion to Population. Interesting correlation could be also between Abortions and Population. A third correlation is Family Planning and Population.

${ }^{35}$ Catholicism allows no divorce. $\mathrm{CO}$ allows a divorce in the case of death, and/or prostitution.

${ }^{36}$ China e.g., in 2015 , allowed a $2^{\text {nd }}$ child to be born.

${ }^{37}$ China is estimated to become the $1^{\text {st }}$ nuclear and military power forming an army of $200 \mathrm{~m}$ when $2 \mathrm{~b}$. 
Humans decomposed the reproduction process in 2 stages! 1) when ${ }^{38}$ a pure love motivates a male to propose to a female for the exclusive purpose of bearing children. 2) To derive satisfaction ${ }^{39}$ from intercourse. Humans, moreover, consider pregnancy as something interruptible and avoidable. ${ }^{40}$

The non-symmetrical distribution curve (Figure 2) shows that in USA, the mass of people get the low incomes and few people obtain the highest ones. Economists and business men alike formed also a new axiom, after 2009, supported by data: "an economic crisis adds greater amounts to the rich and helps new rich to emerge"... Crises create new rich and new poor!

\section{Part 3: Global Population Growth Models}

Let a starting population ${ }^{41}$, (in an isolated location), be $P_{0}$, and assume this to grow by $\alpha(\alpha>0)$, during one generation (Michailidis \& Mpountis, 2017) in Greek. After $1^{\text {st }}$ generation, $P_{0}$ becomes ${ }^{42} P_{0}{ }^{*} \alpha$; in second, $P_{0}{ }^{*} \alpha^{2}$; in third, $P_{0}{ }^{*}$ $\alpha^{3}$, and in $n$ generations:

$$
P_{n}=P_{0} * \alpha^{n}
$$

(for Malthus model-MM, we have $n=1$ and $\alpha=2$ ).

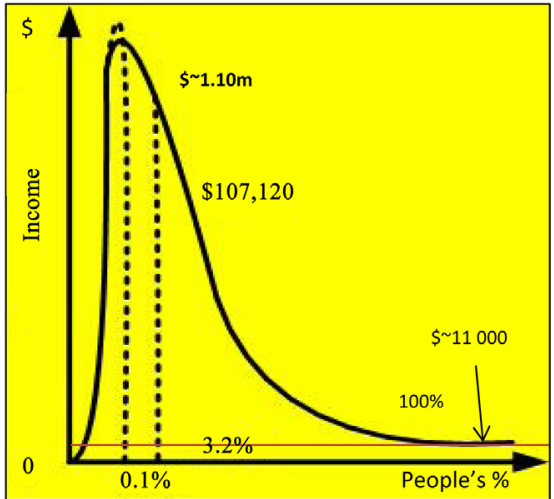

$$
\begin{aligned}
& \text { Pareto's income curve, on lhs, } \\
& \text { shows what actually happens in } \\
& \text { all economies. In USA, the } \\
& \text { minimum year income was } \\
& \$ 11000 \text { (2006?). People getting } \\
& 10 \text { times that were } 3.2 \% \text { ! } \\
& \text { Moreover, } 0.003 \% \text { of people } \\
& \text { earned } ~ \$ 11 \mathrm{~m} \text { per annum; and } \\
& 0.1 \% \text { of people earned } \\
& \sim \$ 1.1 \mathrm{~m} \text { p.a.! } \\
& \text { In } 2018 \text {, globally, about } 198,000 \\
& \text { persons only, had a property of } \\
& \text { over } \$ 30 \mathrm{~m} \text { (Source: "Knight } \\
& \text { Frank") globally! }
\end{aligned}
$$

Figure 2. Pareto's income curve, 1909. Source: modified from that in (Mandelbrot \& Hudson, 2006: p. 154); 295. The formula ${ }^{43}$ used 1s: $P \%=(u / m)^{-\alpha}$ (1): (a power law). This gives the $\%$ of people gaining a certain income $\mathrm{u}$, related to a minimum income $\mathrm{m}$. $\alpha$ by Pareto $^{44}$ found 3.2.

\footnotetext{
${ }^{38}$ Many males fear marriage and the responsibility of children. Many males feel they lose their freedom, when married, and wives believe that births deteriorate their body. Gynecologists argue that all births have to be carried-out by a "Caesarian section", like in the case of Julius Caesar.

${ }^{39}$ Alone or not, with male or female etc. and inside or outside a marriage...

${ }^{40}$ Societies have to establish adequate numbers of "houses for the newly-born babies", which mothers "cannot" have. These babies can be given subsequently for adoption, something that could perhaps terminate babies' trade priced from $\$ 5000$ to 10,000 each (in Greece). Schools have to educate young girls in secondary etc. schools, about unwilling pregnancies, the dangers of abortion and of Aids. Few know that abortion harms mother's psychology, being really an illness.

${ }^{41}$ Malthus could not suspect the number of deaths occurring in modern societies due to road \& air accidents, to use of drugs, terrorists' attacks, climatic change (floods; hurricanes; fires), smoking, suicides, nuclear accidents (Russia; Japan) and Aids... Apropos are the recent massive killings in USA (N. California, Texas, and Ohio, in August 2019).

${ }^{42}$ Population depends on the progress of Medicine, the level of stress and on the quality of nutrition.

${ }^{43}$ Rising $\alpha$ in a negative power; cube it, then find the square root and invert. Alpha is not time-fixed.

${ }^{44}$ Pareto argued that this power law is in the nature of man...
} 


\section{1) Verhulst's Model ${ }^{45}-\mathrm{VM}$}

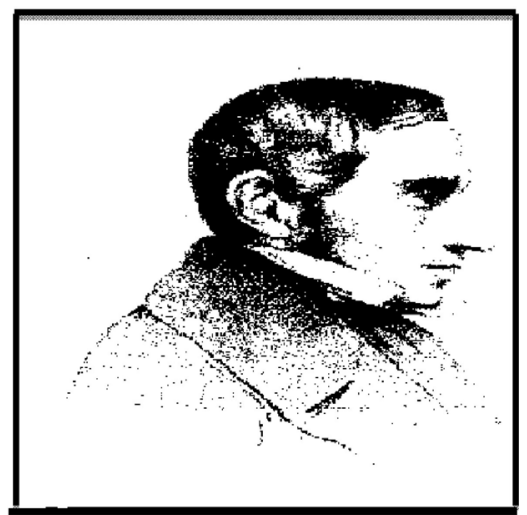

A Belgian mathematician (Verhulst P F (1804-1849)), who in 1838 suggested a model for population, more down to earth, called, in 1845, "logistic". He assumed that the growth of a population depends on maximum one that a location can support. He was professor, in 1835, of Mathematics in the Free University (of Brussels).

Verhulst divided by maximum sustained population, $P_{m}$, all populations. The new variable is:

$$
X_{n}=P_{n} / P_{m}
$$

e.g. for $P_{m}=1000$ and an actual population 100, $X_{n}=0.10$ (i.e. 100 persons $=$ $0.10 * 1000$ ). $X_{n}$, after 10 generations, will reach 0.50 (according to logistic equation); or 500 persons, and it stays there for $\alpha=3.57$ ! So, there is no problem of Malthusian type, as this region is assumed to feed additional 500 (after 250 years! $)^{46}$.

Important is that the $\mathrm{VM}^{47}$ can be used to estimate future population, which would interest Malthus in testing his theory if he cared to knew it, as Verhulst was his contemporary. The population of any next generation multiplied by $\alpha$, and by subtracting those who died ${ }^{18}\left(=\alpha X_{n}^{2}\right)$, is:

$$
X_{n+1}=\alpha X_{n}-\alpha X_{n}^{2}
$$

This equation is a simple quadratic difference equation including time (= dynamic). The MM in the new notation is

$$
X_{n+1}=\alpha X_{n}
$$

There are stable points of equilibrium of population shown by $\{4\}$, after first 4 generations ${ }^{49}$, with an upper limit of $1000 \ldots$... But at this time Chaos comes-in! High rhythms by which humans increase, ( $\alpha$ coefficient $=3.57+$ per generation), invite chaos ... And the stable point does not depend on the starting population

\footnotetext{
${ }^{45}$ Verhulst influenced by Quetelet (1835), who argued that population, cannot grow geometrically over a long period, due to obstacles mentioned already by Malthus.

${ }^{46}$ Verhulst's model pre-assumes a proper place of settlement. Pre-requisites are to have fertile land and water or a river/lake near-by, we believe.

${ }^{47}$ Verhulst's equation was: $P_{t}=P_{o} \mathrm{e}^{r t} / 1+P_{o}\left(\mathrm{e}^{r t}-1\right) / K \quad$ (3) (called logistic ${ }^{\star}$; where total population increases progressively from $P_{o}$, at time $t(=0)$, to a limit $K$, if $t \rightarrow+\infty$. (3) is equivalent to an equation of geometric progression (discrete time). Verhulst argued that a geometric progression is a special case of population with advanced civilization in a fertile territory of unlimited size. $\left(^{*}\right)$ Logistic is a Greek word for feeding an army (commissariat); given also that Verhulst, in 1840, appointed professor at the "Royal Military School" (Brussels).

${ }^{48} \mathrm{VM}$ dealt only with starvation deaths.

${ }^{49}$ Starting generation $=100$; then $180 ; 295 ; 416 ; 486 ; 500 ; 500 ; 500 ; 500 ; 500 ; 500$ !
} 
(of 100 persons we assumed). Even if $P_{0}$ was 900 persons, end population ${ }^{50}$ would be 500 ! Let us see chaos in population closer.

\section{2) Chaos... in Population}

Using the logistic equation $\{4\}$ and for $\alpha=2.2$ and for 4 generations, population will be 550 (from 100). For $\alpha=2.5$ and in 30 generations, population will reach 600. In general:

$$
P_{n}=\alpha-1 / \alpha * 1000
$$

Notable is that for $\alpha=3.2$, we get $513 \ldots$ and 799 , i.e. two populations ${ }^{51}$ ! Given that the limit of population is 1000 , population is well below.

\section{3) Our Model}

$\mathrm{MM}$ and VM can be improved by introducing 2 coefficients: one for fertility $(f)$ and one for mortality $(m)$, as these two may differ, so: $X_{n+1}=f X_{n}-m X_{n}^{2} \quad\{7\}$. Then we can estimate $f$ and $m$ statistically and calculate future population $X_{n+1}$, where $n=1,2,3, \cdots, 100, \cdots$

\section{Part 4: Digital Revolution ${ }^{52}$}

\section{1) Digital Companies}

Globally there are 100 digital top-companies. No Greek shipping or other company is listed. Important is that six are the areas where digital companies act (Table 4).

However, there is an unequal distribution of above companies among the countries, as 98 digital top-companies belong only to 17 countries $^{53}$, showing where digital future lies. Lion's share ${ }^{54}$ is held by USA, with 49 out of the 98 companies (50\%), followed by China with 14 (14\%), Taiwan with 6 (6\%) and EU

Table 4. Specialization of the 100-top digital companies worldwide, 2018.

\begin{tabular}{cccccc}
\hline Retailing & Media & Semi-conductors & $\begin{array}{c}\text { Technology } \\
\text { hardware \& } \\
\text { equipment }\end{array}$ & $\begin{array}{c}\text { IT software } \\
\text { \& services }\end{array}$ & $\begin{array}{c}\text { Aerospace } \\
\text { \& defense }\end{array}$ \\
\hline 6 & 8 & 22 & 26 & 35 & 1 \\
$\begin{array}{c}\text { (e.g. Amazon; } \\
\text { Alibaba) }\end{array}$ & (e.g. Netflix; & $\begin{array}{c}\text { (e.g. NVIDIA; } \\
\text { Intel) }\end{array}$ & $\begin{array}{c}\text { Apple; Dell; } \\
\text { Nokia; Cisco; } \\
\text { Hewlett) }\end{array}$ & $\begin{array}{c}\text { Twitter; Facebook; } \\
\text { Samsung; } \\
\text { Microsoft) }\end{array}$ & (Leidos) \\
\hline
\end{tabular}

Source: Forbes ranking, 2018, where two companies were not classified.

${ }^{50}$ Greeks pay $€ 4$ b p.a. to import medicines! Poor countries import medicines from advanced countries, which prolong life, but they are unable to increase food!

${ }^{51}$ At $\alpha=3+$ the first bifurcation with 2 values starts at $\alpha=3.45$; then we get 4 values, then 8,16 and so on!

${ }^{52}$ The $1^{\text {st }}$ industrial revolution based on steam increased production by mechanization. Next mass production made possible with the aid of electric power, in the $2^{\text {nd }}$ revolution. This revolution had a long evolutionary history; 1889 was the year of a large-scale electric generation. Moreover, industry realized that with no information, leading also to automation, production could not be further increased. Since 1975, till now, electronics and information technology automated production.

${ }^{53}$ Japan 5; S. Korea 4; Netherlands 3; Germany 3; India 3; France 2; Ireland 2; Also, Canada, Finland, S. Africa, UK, Israel, Switzerland, and Luxembourg 1 each, (2 unknown). Greece 0.

${ }^{54} \mathrm{~A}$ report of EC listed the 100 most radical discoveries. See also: "Horizon 2020" and "Horizon Europe” organized by EC's Research and Innovation Directorate. 
with $14(14 \%)(=84 \%)$.

\section{2) Digital Tools and Technology}

Digital technology cannot surprise any manager as it has been already round us (Table 5):

Moreover, digital technology upturned data-poverty we had in the past, and now, big data ${ }^{55}$ are abundant. As a result ways are needed to manage efficiently and effectively them. A company in order to be transformed into digital has to use digital tools and digital technology(Graph 1)! DR is different than previous revolutions, as it focuses not only on higher production and more information, but also on increased knowledge, by providing data ${ }^{56}$ to managers on line.

Which are the digital tools? For the time being are 12 (Table 6):

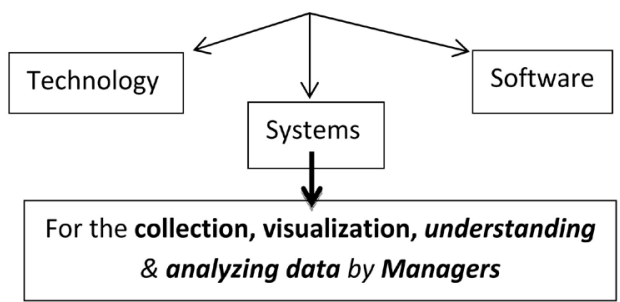

Graph 1. Digital management has to use. Source: Author.

Table 5. Digital technology round us, 2020.

\begin{tabular}{ccc}
\hline $\begin{array}{c}\text { Computers: } \\
\text { (since 1980) }\end{array}$ & Cell phones: & Internet users: from \\
\hline & from 12.5m (1990) to $4 \mathrm{~b}(2016)$ & $2.8 \mathrm{~m}(1990)$ to $1.8 \mathrm{~b}(2020)$ \\
\hline & $\begin{array}{c}\text { Digital software: Microsoft Excel; } \\
\text { on line services from Google analytics } \\
\text { or Networks, connecting computers with people }\end{array}$ \\
\hline
\end{tabular}

Source: author

Table 6. Digital tools (2018).

\begin{tabular}{cccc}
\hline Mobile devices & Artificial intelligence $^{57}-\mathrm{AI}$ & Robotics & Internet of things $^{58}$ \\
\hline Autonomous ships & 4-D printing & Nanotechnology $^{60}$ & Digital technology \\
Materials' science $^{61}$ & Energy storage $^{62}$ & Quantum computing $^{63}$ & Cyber physical systems
\end{tabular}

Source: Author.

${ }^{55} \mathrm{Big}$ data concerns the vast amount of quantifiable information analyzable by highly sophisticated data processing devices.

${ }^{56}$ In-form-ation means data-in-form.

${ }^{57}$ Intelligence demonstrated by machines to help users to solve problems. AI is a set of ideas, of technologies and of techniques related to the ability of a computer's system to execute commands, which under normal circumstances, would require human intelligence. Here we have chatbots and a higher calculating power.

${ }^{58}$ Every day things: to generate, store and share data across internet.

${ }^{59} \mathrm{~A}$ method to an additive construction to create a 3- and 4-D object with materials added together.

${ }^{60}$ Manipulation of a matter on an atomic molecular and super-molecular scale.

${ }^{61}$ The design and discovery of new materials, particularly solid.

${ }^{62}$ To capture energy produced. Important for computers, electric cars, and in saving electric power.

${ }^{63}$ Use of quantum-mechanical phenomena to perform computations.

${ }^{64}$ Mechanisms controlled by computer-based algorithms. 
As shown, a company cannot become digital if not using certain of the above tools. But it also has to use six services:

\section{a) Communications}

For shipping most important are wireless communications, who greatly improved from all places to all places, and at $24 / 7$, by mobile devices (e.g. smart phones). Satellites help in this endeavor in the case of ships. INMARSAT ${ }^{65}$ organization can provide real time analysis of data, including engine monitoring, weather information and fuel consumption.

Also, INMARSAT can help for a higher operational efficiency, safety and compliance to, IT security and crew welfare. The "Marine traffic" can give the route of any vessel. Our interest is in the transmission of picture and sound from the ship to shore-office, primarily when a ship is in a port and secondary when ship is at sea. Classification societies push shipping companies to become digital by offering digital services.

\section{b) Robots}

Robots are used already in shipbuilding ${ }^{66}$. But now small robots can be used in ships to do... repairs on their own. Important is to "look", (and "visit"), using robots, ship's double bottom. The double bottom of a ship needs no more to be as wide as used to be, to accommodate crew, and thus ships can increase cargo-taking. Helpful is also to measure, digitally, the speed of incoming water into the ship in a marine accident, and to know if ship's pumps are coping...

Robots outside human skeleton can help crew to lift very heavy objects as this is required at times onboard or in holds. More important is to prevent crew from entering in closed spaces, where gases kill, using robots. Also in cases of repairs in closed spaces, where robots can pre-test the potential use of fire avoiding an explosion ${ }^{67}$.

\section{c) 4-D printing}

Printers can print... a ship. They also can print the required food by crew. These printers embody time and motion.

\section{d) Computers}

Computers can automatically adjust the operation of ship's main engine and of the 2 generators as well remaining equipment (boiler; evaporator; incinerator etc.), so that to consume the minimum required fuel, diesel, lubricants, chemicals, paint etc. Super computers have now a calculating power unknown before.

e) Artificial Neural Networks-ANN

Ship's machines can learn: 1) to operate with no supervision; 2) to handle new situations; 3) to recognize persons and objects. Onboard we need to prevent unauthorized crew to access ship's cargo, especially containerships, medicines chest, alcohol storage, cigarettes and weapons cabinets, as well provisions. Also, ${ }^{65}$ INMARSAT $=$ international mobile satellite organization.

${ }^{66}$ Technology created new professions. Mankind is obliged to increase educational expenses, as technology "devalued" certain professions... Universities had to teach the new technologies at the pace they crop-up... And what we have to do with persons who become unemployed round their 40s?

${ }^{67}$ Robots can measure the level of oxygen and gasses. 
to see who enters into ship's engine room or using ship's kitchen appliances. ANN can mimic human brain by processing information, and communicating with crew! Automatic reading of boards or texts, and the important Safety Manual, are facilities most helpful to crew, in their mother tongue, and specific guidance of how to approach a port.

Smart tattoos or skin electrodes can monitor influences from environment (pollution); emotions from bad news from home, fatigue or illness, as they provide also health data. There are now monitoring systems that have a speed higher than sound! These systems can recognize from a distance wrecks, a man in the sea, undersea rocks etc. Digital radars may be also used.

\section{f) See from a long distance}

However important all the above, more are the flexible electronic devices, i.e. screens, sensors, batteries and electronic networks etc. These can spread-out on cloth, on paper, and on plastic or ... on human skin. Cameras installed onboard can see everything round an object. Robotic hands can feel changes in sea environment; ball pens can create electronic networks on surfaces. Drones stationed onboard can pre-tell for pirates or terrorists coming...

\section{Part 5: The traditional Management of ships from a long distance}

Generations of shipowners, we presume, dreamed digital management as soon as ceased to be onboard managing their ship from Owner's Cabin! A ship manager, at a certain time, had to leave his/her cabin to undertake the position of manager ashore. This was the result of shipping companies passing, by majority, from a single-ownership to a multi-vessel one, round 1950s.

The above development ended also the romantic-affair between owner and vessel... Vessels since then became "profit-centers", and the only link between owner and vessel remained vessel's christening by crushing a bottle of champagne on ship's cheek at her launching... like a last kiss.

Management from a long distance, after shipowners ceased to be Captains and Merchants at the same time, gave way to Captains, becoming the local managers. A great responsibility passed on them, however. Shipping industry adapted to the new situation by improving the selection of vessels' management (Captains; Chief Engineers). This was an obligatory delegation...but also a passing-over of a substantial risk. Unfortunately, regrets occurred!

Management, from a long distance, had to adopt formalization; i.e. to standardize vessel's jobs, and to guide staff and crew behavior by rules and procedures (mainly written), as the management of ships obtained now a lot of agony and fear. The situation in ships cannot be equal to that in land companies. This is so as formalization in ships is connected also with ship's safety. Thus to break the rules, which is the contemporary trend in non-digital management so that to satisfy customer, cannot be allowed.

Crew has little discretion over what, when and how its work has to be done, not excluding Captain and Chief Engineer. This situation led to a mechanistic structure of shipping companies (Graph 2). The mechanistic organization named also bureaucratic quite rightly, and it is made-up by 6 targets. 


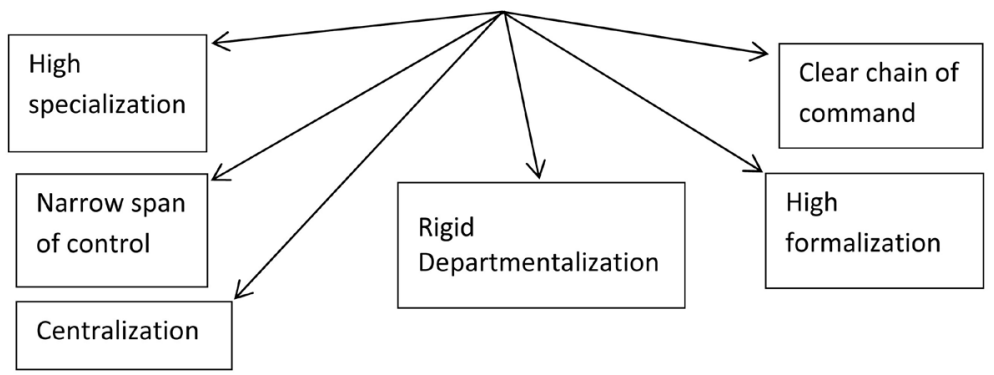

Graph 2. A shipping company in a mechanistic structure. Source: inspired by Robbins \& Coulter, 2018: p. 392.

In above structure, it is necessary to write down all rules and procedures, not only for crew, but also for shore-office staff. Then a top-manager has to have a proper staff at shore-office in suitable quality and quantity, which will supervise the implementation of all these rules and procedures, as well company's budget. The shore staff by necessity is, but not exclusively, former Captains and Engineers, with some 12 - 15 years or more of sea experience.

The above structure fits like a glove to all shipping companies we know. A shipping company is so organized in a number of departments that may reach 20 in large companies. Shipping companies have only 2 divisions: one in the area of Administration, supervising also Office HRM, Public Relations and Secretariat; and one in the area of Economics supervising also Accounts, IT and economic department. Certain shipping companies may have a Controller.

The staff within departments is highly specialized: Sea HRM, Port Captains, Operations and Technical. Non-maritime staff is found in Supply, Insurance, Accounts, Office Personnel \& Public Relations, Secretariat, IT and Chartering. This does not mean that there is no mixed staff, (maritime-non maritime), within these departments. Large shipping companies may have also an S+P department to sell and buy company's ships. They have also a competitive chartering department "competing" with company's chartering department, providing services to customers outside company. Large companies have also a Performance Engineer.

Chartering and Operations are the... royal departments, however, as the first sells company's ship-space to charterers and the $2^{\text {nd }}$ produces services "ordered" by charterers. Without Sales is nothing to produce and without production is nothing to earn. Given that most shipping companies, at least Greek ones, are personal or family ones, their culture is that of Zeus (Figure 3)!

As shown, there is only one source of power: Shipowner-S: a proud and strong personal culture (Onassis; Niarchos), where decisions are taken very fast, as this is imperative for shipping, coupled with perfect timing. The owner provides the resources, and especially capital, has the power, and he inspires discipline. $\mathrm{He} /$ she is known by his/her surname and not by company's name!

Company believes in individuals, not in committees. It judges staff on results. It does not provide succession, but it creates other companies by splitting-up ships to sons, to daughters or to brothers (Goulielmos, 2017). This structure is 


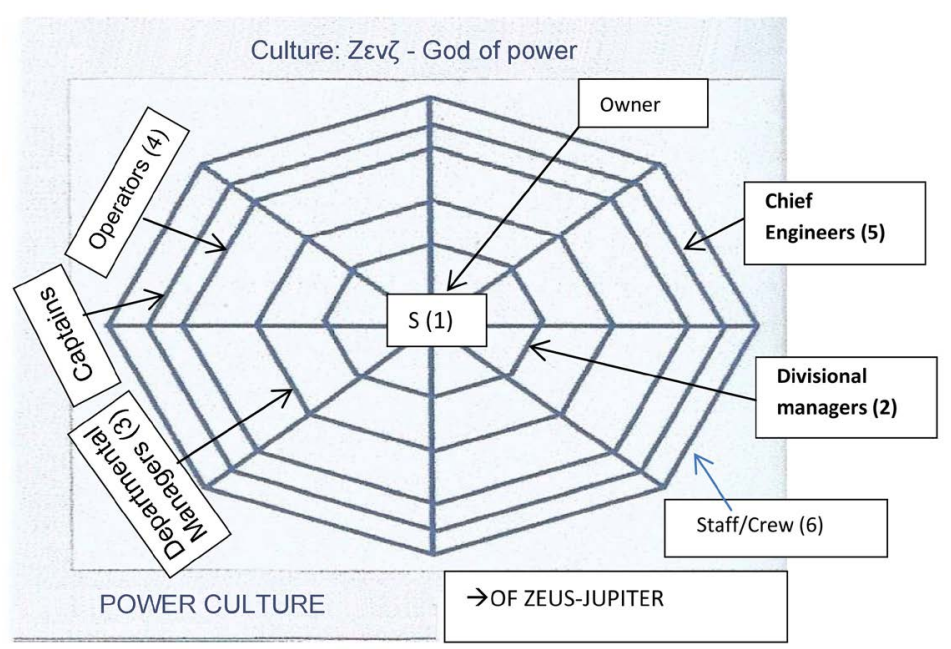

Figure 3. The culture in Greek shipping companies. Source: Author.

centralized $^{68}$, with a narrow span of control ${ }^{69}$. It is tough, though it provides the means required for a mission.

The chain of command is clear. It goes from top-management-S to divisional managers-DM, and from them to departmental managers-DeM and finally to operators-Ops, and then to Captains/Chief Engineers. Managers, divisional and departmental, care for the chain of command so that hierarchy to remain intact. Our theory of managing by attractors due to theory of Chaos is not implemented in shipping, but it should, though attractors are the persons that get company's bonuses or congratulations! This proves that attractors exist.

Shipping companies' structure is made-out intentionally in few hierarchical levels, maximum 4: top-management; divisional managers; departmental managers; operators. This serves to have speed in decision-making and rapid implementation, avoiding time-consuming boards of directors. Computerization increased the speed of decision-making, making structures and hierarchies flatter, and obtaining information directly: computers, quite rightly, do not like hierarchy, while they like attractors!

\section{Part 6: A Digital Ship Management}

Our main interest is to implement digital shipping management the same way international companies manage their activities in various foreign locations, where top-management cannot be present. Worth-watching ship activities are: all shipments from suppliers to the ship; ship's loading/unloading, ship's repairs/maintenance, dry-docking; terrorists' (ISPS Code, 2004) or piracy threats; crew's unrest; ship's delay and ship's proper and economical navigation. This would have the advantage to identify problems in an instant, and act faster.

The $1^{\text {st }}$ change in a shipping company is to establish, at shore office, an "International command \& control center" (ICCC). This will replace traditional map (Scan 1).

\footnotetext{
${ }^{68}$ Decision-making is done by top-management though there is a manual for the authority to sign.

${ }^{69}$ The number of employees a manager can efficiently and effectively manage does not exceed $20-25$ in Greece, and even less (3+). This is different among Germans and Japanese of 1 to 75.
} 


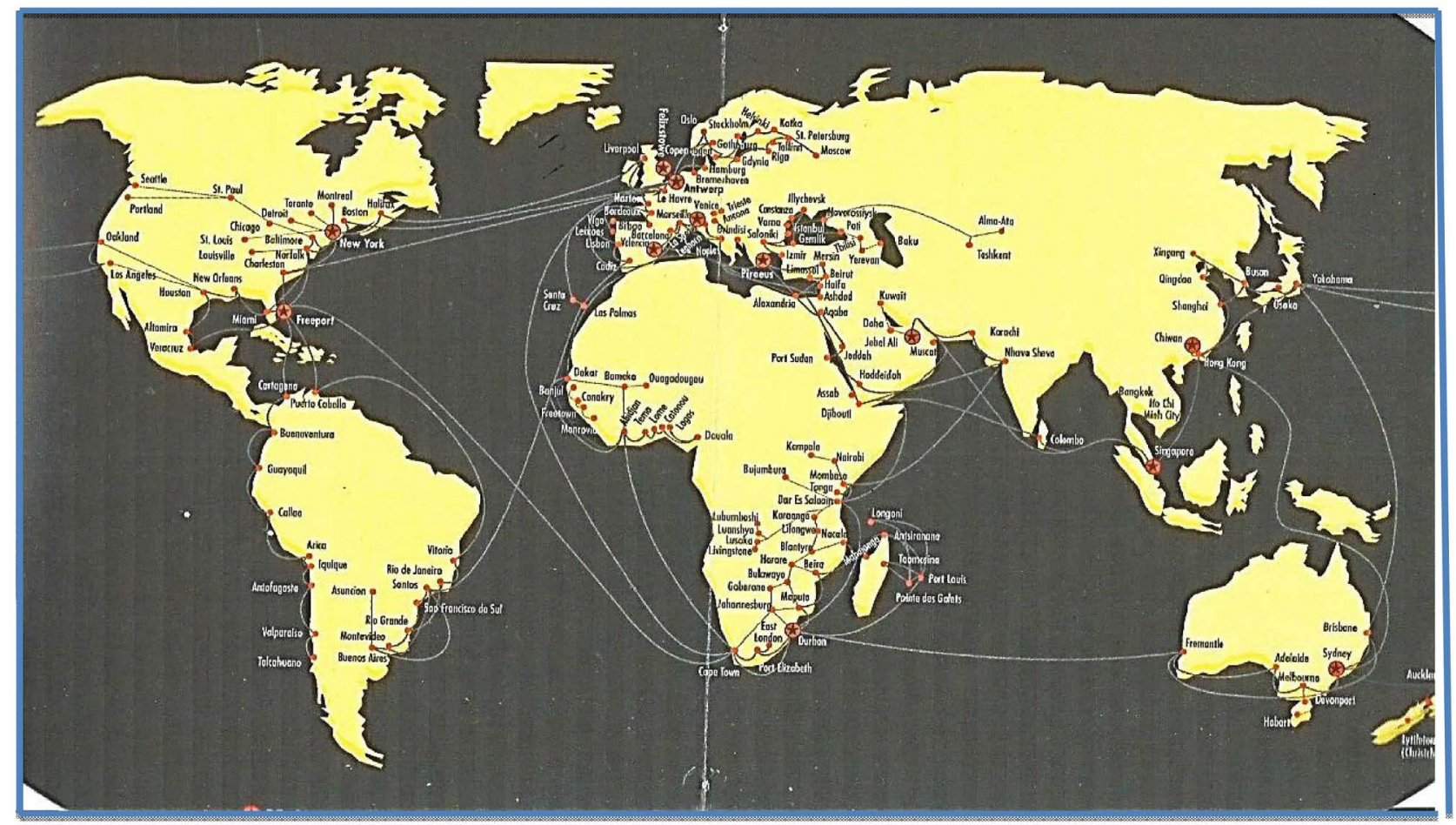

Scan 1. A world map of a large shipping company with networks and "positions" of company's ships and routes shown by pins or flags. Source: Mediterranean shipping company (modified).

These ship positions are up-dated once in 7 days... This ICCC has to be equipped with a number of computer screens, relaying video and data, keeping watch on the operations of company's ships round ports ${ }^{70}$. The "Digital Information Technology"-DIT department has to "digitize ${ }^{71}$ company's operations". Chartering e.g. has to use digital channels to interact with charterers and software to know where and how many competitors are already in the same market.

Shipping companies can also present the agreement with a charterer (the charter party) on screen at the office, and on Captain's computer, codified, and in advance of that the fixture confirmation is presented. Innovative software considers this as a $1^{\text {st }}$ step in ship's production chain, but it can also execute it! Ship's production is planned in a computerized voyage plan in a $2^{\text {nd }}$ step, meaning execution of the charter party, including physical parts (loading; open/close hatch covers; unloading etc.), and showing all relevant services that have to be provided to charterer.

$\mathrm{On}^{72}$ screen is to be shown all relevant influences determining voyage perfor-

\footnotetext{
${ }^{70}$ Like CNN news room with numerous computer-screens relaying video and data and keeping a watch round the world; like Hyundai; like Siemens, which argued that digitalization gives push to productivity (siemens.com/future-of-manufacturing) combining reality with the virtual... one. Entire production chains, or cargo transport, can become more flexible and thus more efficient; companies have now the capability to respond to the demands of every customer (charterer) faster and at the same quality of service.

${ }^{71}$ Recognized by $68 \%$ of respondents (McKinsey, 2018).

${ }^{72} \mathrm{~A}$ charter party is an order for transporting a specific cargo from port A to port B, in safety and in an agreed time, given stated speed, excluding negative influences (sea condition; currents; winds etc.).
} 
mance of the vessel based on a relevant computer program and on information on line provided by INMARSAT. A computer calculates ship's stability and the way of loading properly ship's holds, monitors cargo temperature etc. This software allows a better adaptation of the ship to the provisions of charter party, but it can be also expanded and care for the reduction of operating cost, meaning increased competitiveness.

To achieve the above, we have to use certain digital tools (Graph 3). The adoption of technologies plays here important role, including traditional web tools.

Companies increasingly make strategic changes based on data (business intelligence) (Graph 4).

For business intelligence, data has to be organized so that managers to use them to make more effective strategic decisions. Information on competitors' profits or competitors' market penetration are valuable. In shipping efforts are paid to find-out what other companies pay to their Captains or Chief Engineers, etc., and for provisions' cost.

\section{Conclusion}

Jesus Christ (Son of God; 30 - 33 AD), and Pareto (1909), were clear that the poor will be always among us; and despite... any industrial revolution ${ }^{73}$. The

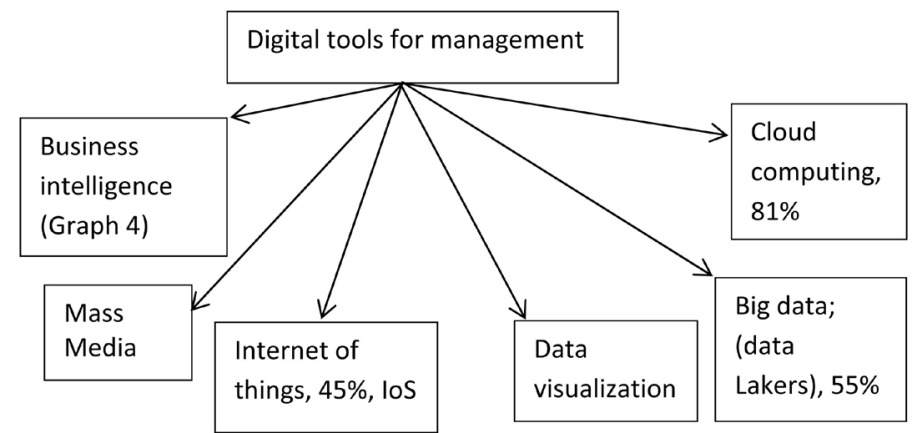

Graph 3. The digital tools for management. Source: Inspired by Robbins \& Coulter, 2018: p. 101; 302-4; mass media added. \% corresponds to positive respondents (McKinsey, 2018).

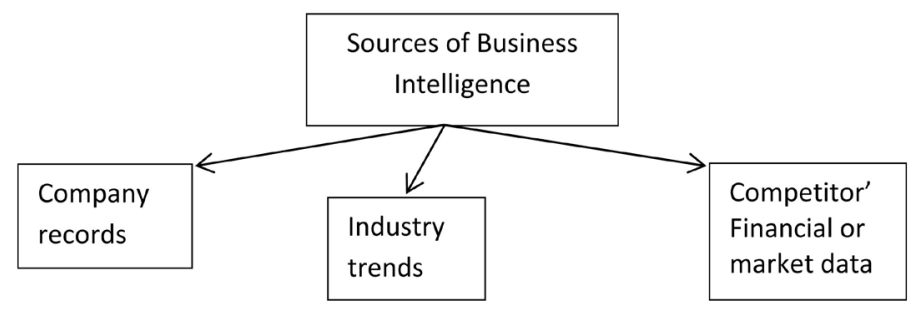

Graph 4. Business intelligence sources. Source: inspired by Robbins \& Coulter, 2018: p. 302.

${ }^{73}$ Revolution is, we believe, if it provides basic goods at low prices. Eventually lower prices emerged only for computers, smart phones, TV sets, and sensors (not an exhaustive list), due to increasing returns to scale (Goulielmos, 2018a). 
industrial revolutions, no doubt, increased substantially quantity ${ }^{74}$ of food so that Malthus' fears not to be verified. But they failed, however, to improve its quality, and par excellence failed to better quality of life, as they should!

History showed that certain great thinkers were utopians, including Einstein, Malthus and Marx. Malthus believed that population will double in 25 years, and then starve... Moreover, Malthus could not imagine that his theory of moral restraint would lead Mr. Place to suggest contraception... And surely he could not figure-out that the abortions could be so popular, so that to invalidate his model...

Remarkable is also with Malthus that he had 3 diverse impacts: in inspiring Mr. Darwin towards... scientific socialism; in supporting Mr. Ricardo to advocate free trade and in leading Mr. Place to suggest contraception! Societies, we believe, are already late in undertaking their Social Revolution. The "misunderstood" Malthus expressed a concern, and a warning, under certain restrictive and unrealistic assumptions, no doubt, towards his society, because he saw that working people could not ever improve their standard of living $g^{75} \ldots$ by creating larger and larger families!

One is, however, surprised to find out that the legal framework of certain countries defined embryo's beginning of life differently.

Verhulst treated Malthus mathematically, without knowing that his simple quadratic equation is a proof of Chaos existence by using a "power dynamic law". He showed that a closed economy can feed a certain (maximum) population, and given that people... die ${ }^{76}$, this maximum will be never reached. A proper model for population's growth had better to be based mainly on two essential propensities, i.e. one to die (mortality) and to one to bear children (fertility).

In digital shipping management, the future is opened brilliant by making the dreams of shipowners-managers to come true enabling them to see into their ships and crew to do things efficiently and effectively...

\section{Conflicts of Interest}

The author declares no conflicts of interest regarding the publication of this paper.

\section{References}

Anonymous (i) (1798). An Essay on the Principle of Population. (ii) Malthus, R. T. (1803). 2nd edition. (iii) Malthus, R. T. (1830). Summary View of the Essay. (iv) Flew, A. (Ed.) (1970). Malthus: An Essay on the Principle of Population and a Summary View. London: Pelican Books, used in this article as a main source on Malthus Theory.

\footnotetext{
${ }^{74}$ If there is an over-production of an agricultural product, which according to law of Supply and Demand, it will obtain a very low price, it is destroyed. Producers should give it free to poor people, to "houses for the aged" and to state hospitals, we believe. This idea is also applicable to products near expiry and spare meals.

${ }^{75}$ This is clear from the subtitle of his essay.

${ }^{76}$ During an economic crisis those that die are more than those they are newly-born!
} 
Blaug, M. (1997). Economic Theory in Retrospect (5th ed.). Cambridge: Cambridge University Press. https://doi.org/10.1017/CBO9780511805639

Darwin, C. R. (i) (1868). Darwin C, autobiography, edited by N Barlow, Collins, 1958. (ii) "The Variations of Animals and Plants under Domestication", J Murray, Vol. 1. (iii) Darwin, C. (1905). “My Life”, Chapman \& Hall, Vol. 1, pp. 361-362.

Daugherty, P., Banerjee, P., Negm, W., \& Alter, A. E. (2015). Driving Unconventional Growth through the Industrial Internet of Things. Accenture Technologies. Pearson Global Edition. http://www.accenture.com/

De la Boutetiere, H., Montagner, A., \& Reich, A. (2019). The Keys to a Successful Digital Transformation.

Engels, F. (i) (1844). Outlines of a Critique of Political Economy. Int. Publisher, NY 1964, p. 222; (ii) An Appendix to K Marx's Economic and Philosophic Manuscript.

Godwin, W. (1793). Enquiry Concerning Political Justice.

Goulielmos, A. M. (2017). The Great Achievement of Greek-Owned Shipping (1946-2017) and Keynes Animal Spirits. Modern Economy, 8, 1186-1210. https://doi.org/10.4236/me.2017.810082

Goulielmos, A. M. (2018a). Self-Reinforcing Mechanisms in Economics with Two CaseStudies from Shipping Industry. Modern Economy, 9, 1313-1337. https://doi.org/10.4236/me.2018.97085

Goulielmos, A. M. (2018b). The Economics of Wealth According to Economic and Religious Principles. Modern Economy, 9, 1465-1489. https://doi.org/10.4236/me.2018.98093

Griffith, E. (2015). What Is Cloud Computing? PC Magazine (on line). http://www.pemag.com/

Jones, R. E., \& Lopez, K. H. (2014). Human Reproduction \& Biology (4th ed.). Cambridge, MA: Academic Press.

Keynes, J. M. (1933). Essays in Biography. London: Macmillan.

Mandelbrot, B. B., \& Hudson, R. (2006; 2008 preface). The Mis-Behavior of Markets: A Fractal View of Risk, Ruin and Reward. New York: Basic Books.

Marshall, A. (1896). The Economics of Industry(2nd ed.). London: Macmillan.

McKinsey (2018). McKinsey \& Company. https://www.mckinsey.com/business-functions/organization/ourinsi

Michailidis, T., \& Mpountis, T. (2017). Talking to Athina about Chaos and Complexity. Athens: Patakis Publications.

Mill, J. S. (1848). Principles of Political Economy.

Ojala, M. (2015). Competitive Intelligence Becomes More Important. Trends E-Magazine, 1-5.

Pareto, V. (1909). Manual of Political Economy. French translation from the Italian edition, reprinted in Oeuvres completes, 1966, Genève, Libraire Droz.

Place, F. (1822). Illustrations and Proofs of the Principle of Population. London: Longman, Hurst, Reeds. Orme \& Brown.

Quetelet, A. (1835). Sur l'omme et le development de ses faculties [A Treatise on Man and the Development of His Faculties]. Paris: Bachelier.

Ricardo, D. (1817). On the Principles of Political Economy and Taxation. Cambridge: Cambridge University Press. (Republished 2015)

Robbins, S. P., \& Coulter, M. (2018). Management (14th ed.). London: Pearson. 
Robinson, J. (1962). Economic Philosophy. London: Penguin Books.

Sen, A. (1973). On Economic Inequality. Oxford: Clarendon Press.

Verhulst, P. F. (1838). Notice on the Law That Population Will Pursue in Its Growth. Correspondence in Mathematical Physics, 10, 113-121. (Translation from French)

Wolfson, R. (2003). Simply Einstein: Relativity Demystified. New York: WW Norton Co.

\section{Appendix}

Great human minds conceived new theories, and certain other, small, derived from them inappropriate suggestions destructive for human lives, like Mr. Place from Mr. Malthus. The same did Mr. Roosevelt from Mr. Einstein. Einstein (1905, 1907) proved $^{77}$ that energy is equal to the square of mass by speed of light. This eventually (1939) led to the construction of atomic bomb (with 129,000 dead in Hiroshima \& 229,000 in Nagasaki in 1945)... For details see Wolfson, 2003: pp. 154-160.

${ }^{77}$ Let (relativistic) kinetic energy $(K)$ be equal to total energy of a particle: $E=K+m c^{2}$. If there is rest, then $K=0$. 